\title{
IBNU BATTUTAH DAN PERKEMBANGAN ILMU GEOGRAFI DI INDONESIA
}

\author{
Oleh : Sukendra Martha
}

\begin{abstract}
Ibnu Battutab as a Muslim geographer and tourist of geograpbical journey bad a great capability for producing a distinguished work respected by Western World. Through bis journey, a part of Indonesia was visited twice in 1345 and in 1346. Therefore, in the development of Geography in Indonesia, a contribution of Ibnu Ballutab cannot be easily ignored. This considered that Batlutah, as geographer could definitely note the results of geographical journey in Indonesia, particularly in Samudera Pasai, Sumatera. A glimpse of Batlutab's biography, and bis contribution to Indonesian Geography are presented in this article.
\end{abstract}

\section{INTTSARI}

Ibnu Battutah sebagai seorang geografiwan Muslim dan pengembara dunia alau journey geografi mempunyai kemampuan bebat dalam menghasilkan karya besar yang dikagumi oleh dunia Barat. Dengan perjalanannya, bagian wilayab Indonesia telab dikunjungi sebanyak dua kali yakni pada tabun 1345 dan tabun 1346. Oleb karena itu dalam perkembangan ilmu geografi di Indonesia, sumbangan Ibnu Battutab tidak dapat diabaikan begitu saja. Hal ini mengingat babva Ballutab, sebagai geografivan tentu telab mencatat basil- hasil perpelancongan geografisnya di Indonesia, kbususnya di Samudera Pasai, Sumatera. Sekilas tentang biografi Battutab dan sumbangannya terhadap Geografi Indonesia disajikan dalam makalab ini.

\section{Sekilas Tentang Geografiwan IBNU BATTUTAH}

Ibnu Battutah dilahirkan di Maroko (lokasi tepatnya Tangier) pada 24 Pebruari 1304 , dengan nama lengkapnya Muhammad bin 'Abdallah bin Battutah. Milicu dan lingkungan Islam dalam kehidupan keluarganya ditandai oleh banyak saudaranya yang menjadi hakimhakim Islam (qadi). Di kota kelahirannya, Tangier, Ibnu Battutah banyak memperoleh pengetahuan atau pendidikan 'syariah' (hukum Islam) dan sastra Islam. Sejak tahun 1325, kesukaan dalam pengembaraan sudah mulai nampak, walaupun dia mulai melan. cong ke tanah suci Mekah dengan niat beribadah haji. Saat itu memang, apa yang menjadi tujuan utamanya adalah betul-betul melaksanakan rukun islam yang kelima. Battutah dalam usahanya memperluas pendidikan dan pengetahuannya tentang Islam adalah menjadi tujuan yang lain dalam pengembaraan, misalnya dapat belajar dari sejumlah sarjana terkenal dari Mesir dan Suriah. Luasnya wawasan berfikir Battutah discbabkan oleh banyaknya belajar dan bergaul dengan para ilmuwan dan ahli sufi. Karirnya sebagai hakim terus 
meningkat berkat pengetahuan ke. islamannya yang luas dan dengan keluasan ilmunya itu Battutah kemudian menjadi hakim tamu yang disegani dan dihormati.

Selama menjadi hakim di pengadilan Battutah masih menyadari belum banyak yang dapat dilakukan untuk kepentingan dakwah. Keinginan untuk turut mensyiarkan agama Islam mungkin secara lebih ekstensif dilakukan dengan perubahan perjalanan hidupnya. Ini dibuktikan dengan beralihnya profesi dari hakim menjadi pelancong. Perubahan perjalanan hidupnya itu diawali semenjak dia berpetualang me. lalui jalan darat ke Mesir melewati Tunis dan Tripoli. Petualangan tadi mulai banyak menarik perhatian Battutah, dengan sabar dia mengamati kondisi geografi setempat dengan berbagai lingkungan bentang alam yang dile. watinya. Selera hati sanubarinya sebagai pelancong geografi kemudian dirasakan lebih sesuai dibandingkan dengan profesi sebelumnya, terutama pada saat masih muda. Hanya olch sebab umurnya yang sudah lanjut (lcbih dari 50 tahun), Battutah baru memutuskan berhenti sebagai pelancong geografi. Kalau tidak ada keterbatasan usia ba. rangkali Battutah akan terus menjalani pengembaraannya dan untuk mengunjungi bagian dunia lebih banyak lagi. Terutama sekali untuk mengunjungi dan mencatat secara rinci mengenai geografi semua negara Islam di dunia ini. Dengan bersemboyankan 'tak akan pernah melewati daerah untuk kedua kalinya', dimaksudkan untuk tidak mengulangi lagi kungjungannya ke dacrah yang sebelumnya pernah dia datangi. Namun dengan memusatkan sistem perjalanan geografi di Mekah sebagai akibatnya beberapa wilayah yang telah dilalui Battutah terpaksa juga harus dilewati lagi dalam perjalanan pulang menuju Mckah. Pcrubahan profesi dari 'qadi' (hakim Islam) ke pelancong geografi dapat dianggap sebagai 'keputusan geografi' yang berat. Keputusan tersebut menghasilkan dampak positif yang besar bagi ilmu Geografi di dunia.

Perjalanan geografi Battutah akhirnya berhenti pada tahun 2357, dan dia kembali menekuni profesi sebelumnya sebagai hakim Islam selama 12 tahun atau 20 tahun lagi sampai dia meninggal dunia pada tahun 1369/1377.

Kunjungan BATTUTAH di Samudra Pasai

Ibnu Battutah pertama kali menginjakkan kakinya di Indonesia (Sumatera) setelah terlebih dahulu mengunjungi pantai Malabar, dan menghabiskan dua tahun lamanya di Pulau-pulau Maldives. Battutah telah mengunjungi Samudera Pasai sebanyak dua kali yakni pada tahun 1345 dan tahun 1346. Persiapan perjalanannya ke Sailan/Sri Lanka, Bengal dan Assam bermula dari situasi politik yang kurang menguntungkan di Pulau Maldives. Pada waktu itu dia memutuskan untuk merangkum misinya ke Cina melalui Indonesia (Sumatera) dan Malaysia. Menurut suatu sumber, di Sumatera Ibnu Battutah diberikan hadiah kapal layar baru oleh seorang sultan Muslim bernama Sultan Malik Dhahir dan setelah itu dia meneruskan pelayarannya ke negeri Cina. Dalam suatu sumber yang lain, yang juga ditulis dalam majalah 'Pertiwi', hadiah dari Sultan Pasai itu bukan berupa kapal akan tetapi berupa scorang gadis dan dua orang pemuda untuk membantu Battulah dalam perjalanan geografi berikutnya. 
Banyak bagian dunia lain yang berhasil dikunjungi Ibnu Battutah, dan apabila digabungkan maka keseluruhan perjalanan geografinya mencapai jarak tempuh lebih dari 120.000 kilometer. Bagian dunia yang telah dikunjungi dapat dibaca dalam 'Perjalanan Geografi seorang cendekiawan Muslim: Ibnu Battutah' (S. Martha, 1991)

Geografi Politik, Sosial Budaya
Samudra Pasai

Kunjungan Ibnu Battutah di Samudera Pasai juga telah dituangkan dalam bukunya (aslinya Bahasa Arab), yang kemudian diterjemahkan ke dalam bahasa Inggris berjudul: Ibnu Battutah, Travels in Asia and Africa 1325. 1354. Buku panduannya berjudul ArRihlah yang terkenal itu merupakan dokumen penting yang mengungkap. kan banyak aspek-aspek politik, sosialekonomi dan budaya dari bagian dunia Islam. Buku ini merupakan sumbangan besar yang sangat berharga dalam perkembangan Geografi dan juga menambah perbendaharaan gaya travel geografi dalam literatur $\Lambda$ rab dan Islam.

Deskripsi geografis Samudera Pasai mengenai geografi politik, sosial budaya masih sangat terbatas. Hal tersebut clapat dimaklumi karena kunjungan Battutah ke Samudera Pasai hanya dilakukan sekilas dalam satu bagian kecil dari keseluruhan kunjungannya ke Cina. Dan walaupun dilakukan dua tahun berturut-turut, kunjungan ke Samudera Pasai tentu belum mewakili seluruh wilayah Nusantara. Menurut penuturan Ibnu Battutah, dalam catatannya mungkin dapat dianggap sebagai deskripsi geografi politik, sosial dan budaya. Deskripsi tersebut menyatakan antara lain bahwa Sultan Pasái adalah seorang muslim yang baik, alim dan disegani masyarakatnya. Kealimannya juga dibuktikan oleh cintanya Sultan akan ilmu- keagamaan terutama Ilmu Tauhid. Sikap Sultan juga dijelaskan sangat terbuka; dan sangat mencintai rakyatnya. Walaupun sistim kerajaan yang dianut, namun kelihatan jelas bahwa Sultan tidak menjalankan pemerintahannya dengan sewenangwenang. Hal ini terbukti akan 'kesa. maan hak; yang ditonjolkan oleh Sultan khususnya dalam kchidupan se. hari-hari. Dalam menjalankan ibadah shalat Jum'at sebagai misal, Sultan selalu memakai pakaian sebagaimana ulama, atau jemaah lainnya, tidak pernah mengenakan pakaian kehesaran kerajaan.

\section{Sumbangan BATTUTAH Terhadap Perkembangan Ilmu Geografi}

Perjalanan geografi Ibnu Battutah yang melewati bagian wilayah Indonesia (Samudera Pasai) itu baik langsung maupun tidak, jelas meru. pakan sumbangsih yang berharga bagi kemajuan ilmu geografi, khususnya di Indonesia. Perjalanan ratusan ribu kilometer dengan kenclaraan tradisional pada saat itu (unta atau kapal layar) yang kemudian dirangkum dalam Ar-Rihlah merupakan karya hesar hasil kerja keras dalam bidang geografi. Oleh karena itu suatu sumber Barat bahkan mengatakan bahwa Ibnu Bat. tutah melampaui perjalanan Marco Polo. Perjalanannya yang meluas itu ternyata sangat menguntungkan ilınu Geografi dan Islam, dan dapat dianggap sebagai turut serta mensyiarkan Islam. Daerah-daerah yang dikunjungi meliputi Mesir, Tunisia, Libya, Suriah, Irak, Iran, Saudi Arabia, Yaman, Tan- 


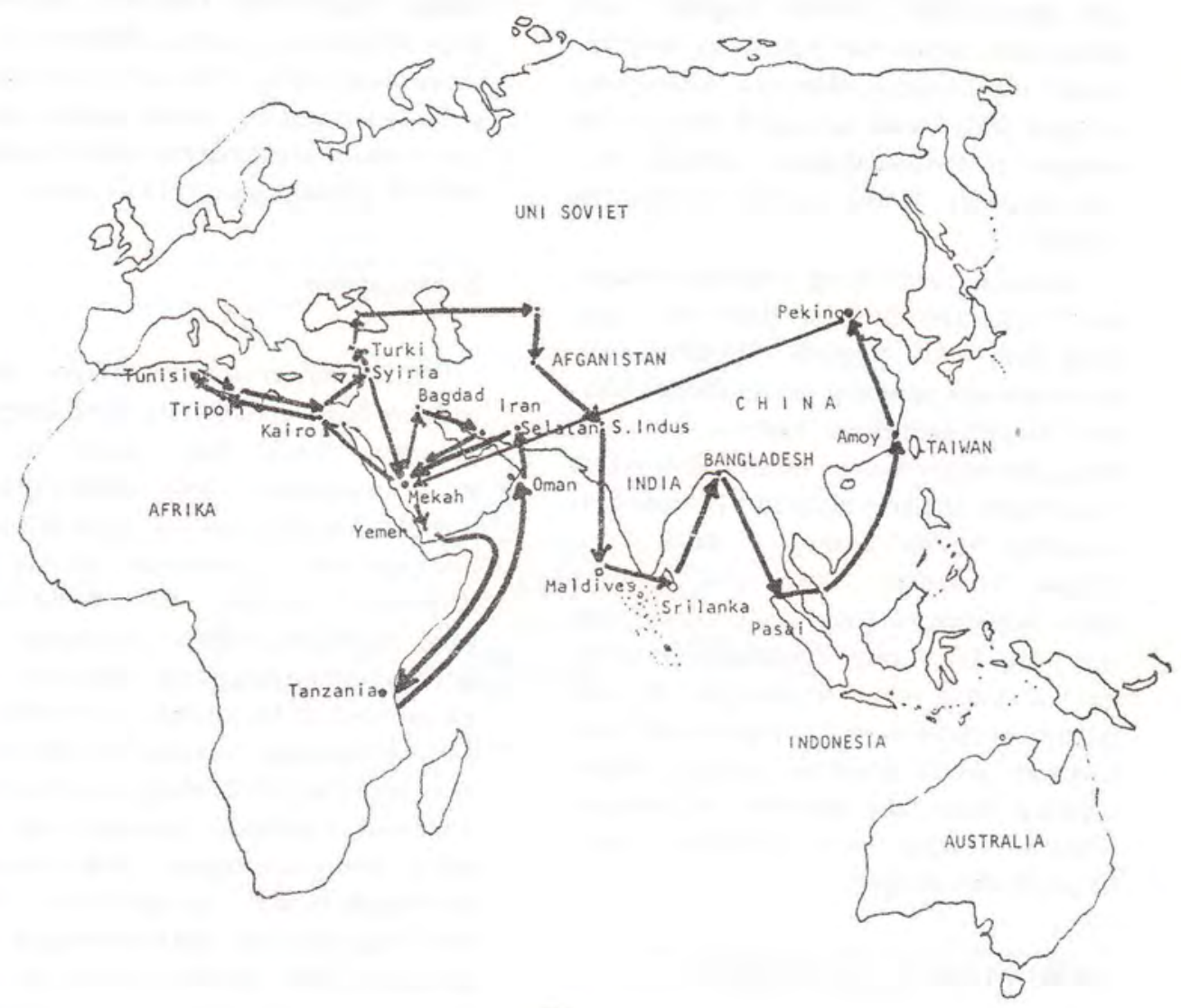

Peta : PERJALANAN GEOGRAFI IBNU BATTUTAH 
zania, Turki, Bulgaria, India, Afganistan, Sri Lanka, Indonesia dan Cina. Kalau kita amati rangkaian perjalanannya, Ibnu Battutah selalu menjadikan Mekah sebagai 'pusat' awal keberangkatan (Lihat Peta Perjalanan Geografi Ibnu Battutah). Motivasi Battutah untuk memilih Mekah sebagai pusat perjalanan adalah bahwa ia dapat menunaikan ibadah hajinya berulang kali (lebih dari tiga kali). Kesempatan ini dimanfaatkannya disamping scbagai pelancong geografi, dia masih sempat menyumbangkan sesuatu untuk dakwah Islam melalui karyanya (bil-fiil)

Suatu hal lagi, yang walaupun hasilhasil rekaman berupa deskripsi geografi fisik tidak banyak diketahui, namun sebagai seorang geografiwan kitapun dapat menduga bahwa Battutah tidak mungkin hanya mendeskripsikan Indonesia tentang keadaan politik dan kearifan Sultan Samudra Pasai saja. Dalam Ar-Rihlah bagaimana kondisi alam lingkungan pada sat itu di tempat yang dikunjungi dijelaskan baik secara tersurat maupun tersirat. Seperti halnya geografiwan lainnya dalam melakukan studi geografi, segala aspek tentang alam dan manusia lingkungan serta hubungan antar keduanya pasti akan dituliskannya.

\section{Perlunya Studi Lebih Lanjut}

Sebagai seorang geografiwan, Battutah tentu telah mencatat semua aspck geografis alam, manusia, politik, sosial-budaya dan lain- lain pada saat dia mendatangi dan mengamati Samudera Pasai. Oleh karena itu seperti disebutkan terdahulu, jikalau sebagian atau seluruh aspek geografis Samudera
Pasai tidak dideskripsikan dalam buku paduan ' $\Lambda$-Rihlah' yang tersohor itu. maka kita patut mempertanyakan untuk mendapatkan alasan maupun jawabannya. Semua itu diperlukan dalam rangka memotivasikan studi lebih lanjut terhadap semua hasil perjalanan geografi Ibnu Battutah di Samudera Pasai hanya dijelaskan sebagai pantainya yang indah. Informasi ini dapat juga ditafsirkan bahwa Samudra Pasai (sekarang Lokhseumawe) belumlah seperti sekarang ini, masih indah, bersih dan belum tercemarkan oleh berbagai limbah industri yang ada di sana.

\section{Kesimpulan}

Dari uraian di atas dapat disimpulkan bahwa Battutah, baik langsung maupun tidak, baik besar maupun kecil mempunyai andil terhadap informasi dalam menunjang perkembangan ilmu geografi di Indonesia. Nlasan yang sederhana adalah bahwa Ar-Rihlah yang menceriterakan perjalanan geografinya menyinggung soal-soal kunjungannya di Indonesia (samudera Pasai). Informasi tersebut berkembang, dan tersebar di berbagai media internasional. Informasi tersebut juga jelas akan menguntungkan baik terhadap perbendaharaan pengetahuan islam dan bagi sejarah perkembangan ilmu geografi pada umumnya dan geografi Indonesia pada khususnya. Ilal tersebut juga mengingat bahwa perjalanan geografi yang dirangkum dalam $\Delta \mathrm{r}$-Rihlah itu memang merupakan karya besar yang patut menjadi kajian geografi, dan sekaligus menarik minat para geografiwan untuk meneliti lebih lanjut meskipun masih bersifat deskriptif. 


\section{REFERENSI}

Ida B., "Aceh Utara Serambi Mekkah", PERTIWI No. 140, Th. Vl, September 1991.

Hayes, J.R., (ed)., Genius of Arab Civilization, Source of Renaissance, New York University Press, New York, 1975.

Martha, S., "Perjalanan Geografi Seorang Cendekiawan Muslim: Ibnu Battutah", Buletin Pengajian, Pengajian Student UNSW Sydney, no. 20/1/1991, 3 Rabiul Tsani 1412/11 Oktober 1991

Strayer, J.R., Dictionary of the Middle Ages, Charles Scribner's Sons, New York.

........, The New Encyclopedia of Britannica, Helen Hemingway Benton, Chicago, 1982. 